\title{
The impact of job resources on employee performance and organizational performance in southwestern railway
}

\author{
Raghavendra Prasanna Kumar ${ }^{1, *}$, V. Murugaiah ${ }^{2}$ \\ ${ }^{1}$ Research Scholar, ${ }^{2}$ Professor, Institute of Management Studies, Davangere University, Davangere, Karnataka, India
}

*Corresponding Author: Raghavendra Prasanna Kumar

Email: raghuhbk1988@gmail.com

\begin{abstract}
The main objective of this study is to predict the impact of job satisfaction (independent variable) on employee performance (mediating variable) and organizational performance (dependent variable). This research will underwrite thoughts on the relationship between job satisfaction and employee performance, job satisfaction and organizational performance and employee performance and organizational performance. The study, based on primary data collected from six hundred (600) group 'c' and group 'd' employees from the southwestern railway. Correlation analysis revealed a favorable association between job satisfaction and employee performance, job satisfaction and organizational performance, and employee performance and organizational performance. Further analysis showed that employee performance is significantly mediating the relationship between job satisfaction and organizational performance. The outcome of the study is discussed, together with limitations and suggestions for future research.
\end{abstract}

Keywords: Job satisfaction, Employee performance, Organizational performance, Southwestern railway.

\section{Introduction}

Job satisfaction is one of the broadest analysis topics in the organizational behavior and psychology. Satisfaction within the workplace is cherished to review for many causes, like worker job satisfaction ends up in a raise within the productivity of the organization and to determine the humanitarian price of promoting employee satisfaction within the geographic point (Smith et al., 1969).

Job satisfaction purposefully ends up in a positive outcome for the people to extend the executive social responsibility behavior, (Organ \& Ryan, 1995), redoubled life happiness (Judge, 2000), reduced counterproductive work behaviors (Dalal, 2005), and declined absenteeism (Hardy, Woods, \& Wall, 2003).

According to the job characteristics defined by Hackman and Oldham (1975), as a result of the psychological feature ability, below and over-qualified for his or her jobs can probably ask for different employment opportunities that area unit a higher match for his or her skills. Supported this development, people having high psychological feature ability can get, the most senior jobs and such jobs have additional responsibilities, the management pays the very best remuneration that ends up in the task satisfactorily.

\section{Literature Review}

Job Satisfaction: Savery (1989) organizations should specialize in satisfying the three basic wants (Individual motivators, worker relationships, and private relationships) of a worker which can reciprocally facilitate the workers in achieving job satisfaction. Burke R.J and MacDermid (1999) studied the task satisfaction level of compulsives and aforesaid; there is a unit six varieties of workaholic patterns, i.e., Workaholics, zealous Workaholics, Work zealous, Unengaged staff, Relaxed staff, and knowledgeable staff. Beumont (1982) explained the task satisfaction level of general family within the U.S, wherever in there's a particular work relationship with the U.S than Great Britain. Within the study, he found that within the U.S, there's a positive relationship between Job Satisfaction and Age, whereas in Great Britain it had been significantly lower. Berghe. J. V (2011) over within the thesis, the assessment of job structures on job satisfaction established with the help of the Two-Factor Theory and the Job Characteristics Model. The impact of others on job satisfaction conferred as direct and indirect. The result of private inclinations on job satisfaction classified consistent with genetic characteristics, emotional desires, age, and gender. Consistent with Saks (2006), job engagement is allied to job satisfaction, organizational commitment, and organizational citizenship behavior, and undesirably associated with intent to quit.

Organizational Performance: Abu Bakar et al. (2016) scrutinized the relationship between knowledge management practices and growth performance in the construction industry. Growth performance measurement assumed through company turnover and employment progress. The results show that knowledge creation, storage, transfer, and application have a significant relationship with growth performance. Tan \& Wong (2015) examined the result of knowledge management in industrial performance, which defined as fabrication and functioning recital measured as quality, time, cost, flexibility, and customer satisfaction. Results showed that knowledge management processes and factors have significant and direct effects on manufacturing performance. Organisational performance is an essential indicator of organizational success (Stegerean \& Gavrea 2010). Employees skill levels also related to attain organizational objectives, and also create a good working atmosphere (Carvalho et al. 2016).

Employee Performance: Employee performance typically observed in regards to the consequences. It could also be seen in concerning of conduct (Armstrong 2000). Kenney et al. (1992) employees' performance measured by comparing the performance measuring performance, for example, using 
productivity, efficiency, effectiveness, quality and profitability measures. It expressed as the ratio of gross profit to sales or return on capital employed (Wood \& Stangster 2002). Wright \& Geroy (2001) through the effective training program, employees' competencies could change and improves the overall performance effectively.

The Research Gap: It's discovered that earlier studies explore the connection between job satisfaction and organizational performance. So, there's an opportunity to check the link between job satisfaction and organizational performance through employee performance as a mediating variable. Thus, research article entitled 'The impact of job resources on employee performance and organizational performance in southwestern railway.'

\section{Objectives of the Study}

The purpose of the study is to examine the connection between job satisfaction and organizational performance with the mediating role of employee performance. Supported this development author justify the impact of job satisfaction on organizational performance. The most important thought is employee performance is predicated on the task satisfaction of workers and plays a crucial role in raising the organizational performance.

\section{Materials and Methods}

Research Design: This research is evidence-based and empirical. The research design is comprised of three major components.

1. Sampling procedure

2. Data sources

3. Statistical tools

\section{Sampling Procedure}

Target Respondents: The population targeted in this study included permanent. Group C employees (Station Masters, Commercial Clerks, and Civil Engineers, etc.) and Group D (Pointsman, Gateman, and Trackman) employees in the southwestern railway.

Sample Unit: One employee from group c is considered as one unit, and one employee from group $\mathrm{d}$ is considered as one unit from all the three divisions (Hubli, Bangalore and Mysore).

Sampling Method: For this research, a non-probability sampling design in the form of a representative convenience sampling method. The justification for using this sampling method was due to the time constraints and inexpensive to gather the research information.

The questionnaires administered in a controlled environment. The objectives of the survey clarified to the partakers at their place of work. Confidentiality and anonymity were assured.

Sample Size: The sample $(n=600)$ comprised of male and female, permanent employees in southwestern railway. Group C and Group D employees are working in the railway station jurisdiction, and they have to perform the task in a team and face similar situations.

Data Sources: Hence, this pilot study helped to get in-depth knowledge of workforce diversity and employee engagement, and the same has incorporated in the survey for the best possible outcomes.

Primary Data: Self-Administered and Structured questionnaire is used to collect the primary data (five-point Likert scale) from the Group ' $\mathrm{C}$ ' and Group ' $\mathrm{D}$ ' employees. Before analyzing the data, examined the reliability of the variables through Cronbach's alpha to ensure the completeness.

Secondary Data: Secondary data collected from various journals, textbooks, internet, newspapers, and magazines.

Statistical Tools: Mediating effects calculated by using the Process Macro created by Andrew. F. Hayes. Internal consistency, measured with the Cronbach alpha (Clark \& Watson 1995).

According to the table-1, the majority of the respondents are male (85\%), and $36.3 \%$ of the group between the ages of 21 and 30 years, $61 \%$ of the salary of respondents between 30001-40000, 79.5\% of the participant's mother tongue Kannada, $75 \%$ of the participants are married, and $63 \%$ of the respondents have passed the SSLC.

Measuring Instruments: This study has three measuring instruments, namely the job satisfaction (Smith S, 2018), organizational performance, employee performance (selfadministered) and a demographic questionnaire (gender, age, mother tongue, marital status, and educational qualifications).

Job satisfaction restrained with ten items ("I feel encouraged to come up with new and better ways of doing things). Organizational performance restrained with seven items (Improved teamwork). Employee Performance measured with five items (They will care about the quality of their work). Above all the statements include five response options whereby $1=$ Strongly Disagree to $5=$ Strongly Agree.

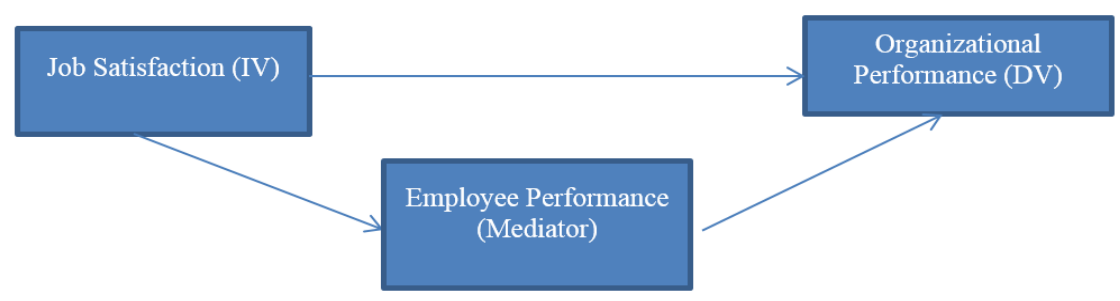

Note: $I V=$ Independent Variable, $D V=$ Dependent Variable

Fig. 1 Conceptual model (Based on literature review) 


\section{Results}

Table 1: Demographic characteristics of the respondents

\begin{tabular}{|c|c|c|c|c|c|}
\hline S. No. & Item & M & SD & Category & Percentage \\
\hline \multirow{2}{*}{ N. 1 (vo. } & \multirow[t]{2}{*}{ Gender } & \multirow[t]{2}{*}{1.15} & \multirow[t]{2}{*}{.35} & Male & 85 \\
\hline & & & & Female & 15 \\
\hline \multirow[t]{4}{*}{2} & \multirow[t]{4}{*}{ Age } & \multirow[t]{4}{*}{2.15} & \multirow[t]{4}{*}{1.03} & $21-30$ & 36.3 \\
\hline & & & & $31-40$ & 22.2 \\
\hline & & & & $41-50$ & 31.2 \\
\hline & & & & $51-60$ & 10.3 \\
\hline \multirow[t]{4}{*}{3} & \multirow[t]{4}{*}{ Salary } & \multirow[t]{4}{*}{2.17} & \multirow[t]{4}{*}{.73} & 20000 & 14 \\
\hline & & & & $20001-30000$ & 61 \\
\hline & & & & $30001-40000$ & 19 \\
\hline & & & & $40001-50000$ & 6 \\
\hline \multirow[t]{3}{*}{4} & \multirow[t]{3}{*}{ Mother Tongue } & \multirow[t]{3}{*}{1.30} & \multirow[t]{3}{*}{.66} & Kannada & 79.5 \\
\hline & & & & Hindi & 9.0 \\
\hline & & & & Telugu & 11.5 \\
\hline \multirow[t]{4}{*}{5} & \multirow[t]{4}{*}{ Qualifications } & \multirow[t]{4}{*}{1.56} & \multirow[t]{4}{*}{.81} & SSLC & 63.0 \\
\hline & & & & PUC & 18.7 \\
\hline & & & & UG & 17.0 \\
\hline & & & & $\mathrm{PG}$ & 1.3 \\
\hline
\end{tabular}

Table 2: Means, standard deviations, inter-correlations, and internal-consistencies of the scale used in the study $(\mathbf{N}=600)$

\begin{tabular}{|c|c|c|c|c|c|c|}
\hline S. No & Variable & M & SD & 1 & 2 & 3 \\
\hline 1 & Job satisfaction & 41.25 & 7.63 & $(0.84)$ & & \\
\hline 2 & Employee Performance & 18.71 & 4.24 & $0.77 * *$ & $(0.72)$ & \\
\hline 3 & $\begin{array}{l}\text { Organizational } \\
\text { Performance }\end{array}$ & 23.26 & 5.42 & $0.58 * *$ & $0.78 * *$ & $(0.62)$ \\
\hline \multicolumn{7}{|c|}{$\begin{array}{l}\text { Note:1. In bracket bold, italic values indicate Cronbach alpha. } \\
\text { 2. ** @ } 1 \% \text { level of significance. } \\
\text { Source: prepared by the authors. }\end{array}$} \\
\hline
\end{tabular}

Table 2 presents mean scores, standard deviations, reliability indices, and correlations between the study variables. All scales showed acceptable reliabilities. Job satisfaction and organizational performance were moderately correlated $(\mathrm{r}=0.581, \mathrm{p}<0.01)$. Job satisfaction and employee performance were highly correlated $(\mathrm{r}=$ $0.773, \mathrm{p}<0.01$ ), and employee performance and organizational performance were highly correlated $(\mathrm{r}=$ $0.782, \mathrm{p}<0.01)$.

Table 3: Employee performance is mediating the relationship between job satisfaction and organizational performance.

\begin{tabular}{|l|l|l|c|c|c|c|c|c|c|}
\hline Steps & \multicolumn{1}{|c|}{$\mathbf{I V}$} & $\mathbf{D V}$ & $\mathbf{F}$ & $\mathbf{R}$ & $\mathbf{R}^{2}$ & Adj R $^{2}$ & $\mathbf{B}$ & $\mathbf{S E}$ & $\mathbf{P}$ \\
\hline 1 & Job satisfaction & $\begin{array}{c}\text { Organizational } \\
\text { Performance }\end{array}$ & 886.5 & 0.58 & 0.34 & 0.34 & 0.41 & 0.02 & 0.00 \\
\hline 2 & Job satisfaction & $\begin{array}{c}\text { Employee } \\
\text { Performance }\end{array}$ & 304.2 & 0.77 & 0.59 & 0.59 & 0.46 & 0.02 & 0.00 \\
\hline 3 & $\begin{array}{l}\text { Employee } \\
\text { Performance }\end{array}$ & $\begin{array}{c}\text { Organizational } \\
\text { Performance }\end{array}$ & 941.2 & 0.78 & 0.61 & 0.61 & 0.93 & 0.03 & 0.00 \\
\hline 4 & Job satisfaction & $\begin{array}{l}\text { Organizational } \\
\text { Performance } \\
\text { Performance }\end{array}$ & 472.5 & 0.78 & -- & -- & 0.99 & 0.04 & 0.145 \\
\hline 5 & JS*EP= OP & & & & & & \\
\hline
\end{tabular}


Table 3 reveals the values of mediated regression are used to test the mediation effect of employee performance between job satisfaction and organizational performance.

A significant relationship between job satisfaction and organizational performance $(\mathrm{r}=0.58, \mathrm{P}<0.01)$, job satisfaction have $34 \%$ of the modification in organizational performance. For each unit escalation in job satisfaction, 0.41 unit increase in organizational performance.

There is a favorable correlation between job satisfaction and employee performance $(\mathrm{r}=0.77, \mathrm{P}<0.01)$, with job satisfaction accounting for $59 \%$ of the variance in employee performance. The results revealed an employee performance that has a significant impact on organizational performance $(0.78)$ with the positive value. The two variables are significantly correlated $(\mathrm{r}=0.78, \mathrm{P}<0.01)$.

Job satisfaction explains a further $61 \%$ of the variance in organizational performance after controlling the employee performance. There is an increase from $34 \%$ of shared variance to $61 \%$ of the pooled difference in step four. So, we can conclude mediation exists.

Job satisfaction has a direct effect -0.04 and indirect (with the mediation of employee performance) 0.45 total effect of 0.41 on organizational performance. It implies that when job satisfaction goes up by one, the organizational performance will have a negative impact -0.04. It is also significant to note that organizational performance $(0.99)$ will be more when employee performance is mediating the relationship between job satisfaction and organizational performance.

The Sobel test results are summarized. It showed that the consistent regression analysis with engagement as the conditions generated the subsequent results: $a=-0.04, b=$ $0.99, \mathrm{sa}=0.02, \mathrm{sb}=0.04$.

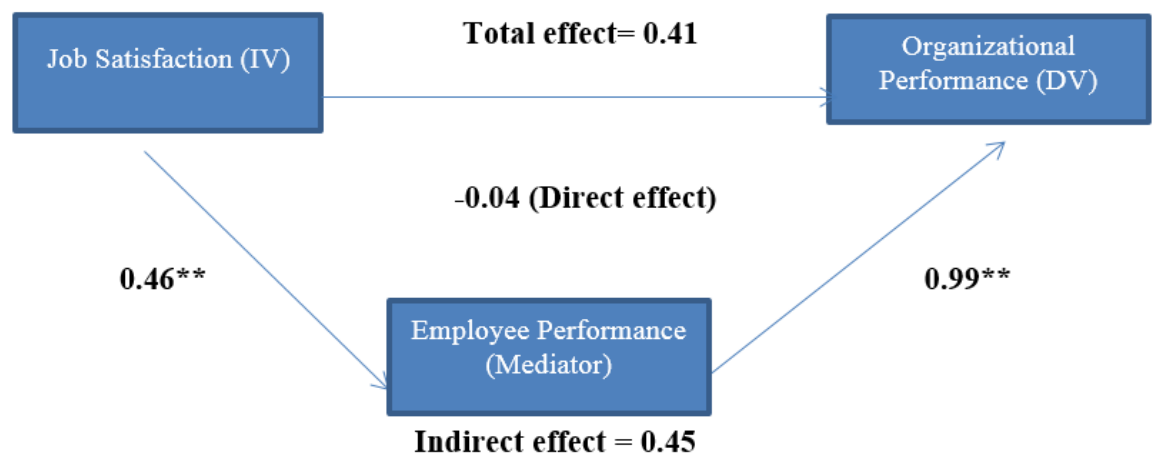

Fig. 1.1: Path coefficients of the variables (including mediation effect)

Fig. 1.1 provides the relationship between, job satisfaction (independent variable) and employee performance (mediator), job satisfaction and organizational performance (dependent variable), and employee performance to organizational performance.

Table 4: Sobel test results for employee performance mediating the relationship between job satisfaction and organizational performance

\begin{tabular}{|l|c|c|c|c|c|c|c|}
\hline \multicolumn{1}{|c|}{ Indirect Effect } & A & b & sa & Sb & Z & se & p \\
\hline $\begin{array}{l}\text { Job Satisfaction } \rightarrow \text { Employee } \\
\text { Performance } \rightarrow \text { Organizational } \\
\text { Performance }\end{array}$ & 0.46 & 0.99 & .02 & .04 & 16.84 & 0.02 & .000 \\
\hline Source: Authors' calculation & & & & & & & \\
\hline
\end{tabular}

The table 4 reveals observed p-value of less than 0.05 and, confirmed that the employee performance has a significant mediating effect on organizational performance $(\mathrm{z}=16.84, \mathrm{p}<0.01)$. The Sobel test results, therefore, established that employee performance indeed mediated the relationships between job satisfaction and organizational performance.

\section{Discussion}

The main findings of this research are, Pearson correlation analysis reveals (table-2) job satisfaction is highly correlated with employee performance $\left(0.77^{* *}, \mathrm{P}<\right.$
0.01 ), whereas job satisfaction has a moderate correlation with the organizational performance $\left(0.58^{* *}, \mathrm{P}<0.01\right)$. Finally, employee performance, highly correlated with the organizational performance $\left(0.78^{* *}, \mathrm{P}<0.01\right)$.

From the results it can be understood, organizational performance is not dependent on job satisfaction, employee performance in the organization will give the positive results by achieving the objectives. Job satisfaction alone cannot be the determinant factor for organizational performance. The job satisfaction strongly determines employee performance. Organizational performance is 
going better with the job satisfaction and employee performance.

It is essential to know that job satisfaction is available from the positive working environment, reward and recognition of employees. Job satisfaction is acute in elevation productivity, motivation and low employee turnover. The leaders face the encounters of verdict methods to increase the job satisfaction. Managers face the contests of preserving efficiency, effectiveness as well as charge their workforce engaged and satisfied with their jobs.

The job satisfaction of an employee will improve the employee performance after making certain employees are vibrant about their work duties means communicating those expectations well. Job satisfaction helps to continue to manage what is predictable through frequent communications. For ex: an employee can describe the aims in his own words, it is a moral coincidental that they know what to do and how to get it done.

Job satisfaction of the employees enhances the employee performance, and organizational performance is dependent on the employee performance. Berghe. J. V (2011) argued that the relationship between job satisfaction and job performance has, the weaker correlation, and job performance as a backing element to job satisfaction and also produced unconvincing results.

Brayfield and Crockett (1955) completed the first metaanalysis about the relationship between job satisfaction and job performance and only obtained a weak correlation between the two variables. In sometimes employees will have more job satisfaction, but inert well-thought-out dissatisfied in the workplace.

Job satisfaction is an approach to an employee from his job, based on this, the influences of satisfaction and dissatisfaction will be fluctuating over the time. It is recycled as a strategic cause to measure the performance of an individual employee and the organization.

If employees' performance is better, then it leads to increase the organizational outcomes. The different levels of job satisfaction such as teamwork, creating a positive working environment, autonomy predicts the organizational performance. Employees reliability is considered to be an essential factor in the growth and development of the organization. The organization, to achieve outstanding achievements, needs its workforce behaving in such a manner to enable its activities.

In a business context, generally, the only behavior that is scrutinized the employees'. The human resources can control their actions and response to some extent, and this is only one facet of attaining exceptional outcomes. Management to some extent also controls the workforce through hiring practices, task assignments, oversight, training and education, recognition, and incentives.

\section{Conclusion}

This research work heaves some graceful on the importance of job satisfaction and employee performance on organizational performance. The correlation analysis confirmed that job satisfaction and organizational performance was moderately correlated $(\mathrm{r}=0.581, \mathrm{p}<$ 0.01 ), job satisfaction and employee performance were highly correlated $(\mathrm{r}=0.773, \mathrm{p}<0.01)$, and employee performance and organizational performance were highly correlated $(r=0.782, p<0.01)$, and a step-wise regression analysis was conducted to determine the mediation effect of employee performance between the job satisfaction and organizational performance by showing the interactions between job satisfaction, and employee performance, job satisfaction and organizational performance, and also employee performance with job satisfaction and organizational performance.

After testing the results from the regression, the Sobel test also confirmed the mediation effect, i.e., Along with the job satisfaction, employee performance is essential for the organizational performance. Results suggest that job satisfaction alone is not sufficient for the organizational performance. The combination of job satisfaction and employee performance will play an essential role in improving the organizational performance.

Despite the substantial theoretical interest in job satisfaction, there is a relative shortage of literature investigating the impact of employee performance as a mediating factor in the global context. Thus the existing study renders insights into the relationship between job satisfaction and organizational performance in the global context.

\section{Managerial Implications}

The research model in this study needs to further evaluate by additional studies. Nevertheless, it has practical implications for improving organizational performance. From the organization viewpoint intervention of employee performance is suggested. Organizations concerned with the job satisfaction of the employees in the workplace to boost the employee performance. Top management could attempt to clarify the roles and responsibilities of the employees which leads to happiness and identify the goals and objectives of the organization to direct the employees and accomplish the task.

\section{Contribution of the Study}

This study will add value to the existing body of knowledge that exists in the area of job satisfaction, organizational performance, and employee performance. To the Indian Railways, the findings of this study will enable policymakers to address the need for job satisfaction, organizational performance, and employee performance. In this regard, Indian Railways should formulate the policy strategies to enhance the job satisfaction to develop the organizational performance and employee performance.

Additionally, the results of this study will help other service sectors to implement the human resource practice that impacts positively on job satisfaction which results in organizational performance and employee performance.

This research serves as literature in their further survey on job satisfaction, organizational performance, and 
employee performance. Further, academicians will review the existing literature and establish a gap for future studies.

\section{Limitations and Suggestions for Future Research}

The present study focuses only on Indian Railways. The study group comprised group c and group d employees as a representative sample of the southwestern railway, Indian Railways. Further, there are more opportunities to research on the topic of job satisfaction, employee performance, and organizational performance of the various services sectors such as airlines, state road transportations of different states in India. Apart from this researcher and scholars can use the different variables subject to the organizations.

\section{Conflict of Interest: None.}

\section{References}

1. Abu Bakar, A. H., Yusof, M. N., Tufail, M. A., \& Virgiyanti, W. (2016). Effect of knowledge management on growth performance in construction industry. Management Decision, 2016;54(3):735-749. https://doi.org/10.1108/MD-01-20150006.

2. Hayes, A. F. (2012). PROCESS: A versatile computational tool for observed variable mediation, moderation, and conditional process modeling [White paper]. Retrieved from http://www.afhayes.com/ public/process2012.pdf

3. Ahuja, K. 2006. Personnel management. 3rd Ed. New Delhi. India. Kalyani publishers,

4. Armstrong, M. (2009). Armstrong's Handbook of Performance Management: an Evidence-based Guide to Delivering High Performance. (4th ed.). London: Kogan Page.

5. Ashforth, B. E., \& Humphrey, R. H. Emotional labor in service roles: The influence of identity. Academy of Management Review, 1993;18:88-115.

6. Berghe. J. V (2011). Job Satisfaction and Job Performance at the Work Place.

7. Brayfield, A. H., \& Crockett, W. H. (1955). Employee attitudes and employee performance. Psychological Bulletin, 1955;52(5):396-424. http://dx.doi.org/10.1037/h0045899

8. Burke.R.J and MacDermid.G (1999) "Are workaholics job satisfied and successful in their careers?", Career Development International, Vol. 4 Issue: 5, pp.277-282, https://doi.org/10.1108/13620439910279761

9. Carvalho, A.O., Ribeiro, I., Cirani, C.B.S. \& Cintra, R.F. 'Organisational resilience: A comparative study between innovative and non-innovative companies based on the financial performance analysis', International Review of Applied Economics. 2016;25(1):61-85.

10. Clark and Watson. Constructing Validity: Basic Issues in Objective Scale Development. Psychological Assessment. 1995;7(3):309-319.

11. Dalal. R.S. A meta-analysis of the relationship between organizational citizenship behavior and counterproductive work behavior. J Appl Psychol. 2005;90(6):1241-55.

12. Fletcher, C. (2010). Appraisal, Feedback and Development: Making Performance Review Work. (4thed.). London: Routledge.
13. Glasow, P.A. (2005). Fundamentals of survey research methodology. Retrieved January 18, 2013, from http://www.mitre.org/work/tech_papers/tech_ papers_05/05_0638/05_0638.pdf.

14. Hardy GE, Woods D, Wall TD (2003), The impact of psychological distress on absence from work. J Appl Psychol. 2003;88(2):306-14.

15. Jeremy Melvin, (1993) "Design and the Creation of Job Satisfaction", Facilities. 1993;11(4):15-18, https://doi.org/10.1108/EUM0000000002235

16. Judge, T. A., \& Church, A. H. (2000). Job satisfaction: Research and practice. In C. L. Cooper \& E. A. Locke (Eds.), Industrial and organizational psychology: Linking theory with practice (pp. 166-198). Oxford, UK: Blackwell.

17. Kenney et al, (1992) Management Made East. 1st Ed. South Carolina: Omron Publishers.

18. Mafni, C., \& Pooe, D.R.I. (2013). The relationship between employee satisfaction and organizational performance: Evidence from a South African government department. SA Journal of Industrial Psychology.

19. Organ, D. W., \& Ryan, K. (1995). A meta-analytic review of attitudes and dispositional predictors of organizational citizenship behavior, Personnel Psychology, 48, 775-802.

20. Lawson K. Savery. Job Satisfaction and Nurses. Journal of Managerial Psychology. 1989;4(5):11-16. https://doi.org/10.1108/EUM0000000001727

21. Saks. A.M. Antecedents and consequences of employee engagement. Journal of Managerial Psychology. 2006;21(7):600-619. https://doi.org/10.1108/02683940610690169

22. Smith, P. C., Kendall, L. M., \& Hulin, C. L. (1969). The measurement of satisfaction in work and retirement. Chicago: Rand McNally.

23. Stegerean, R. \& Gavrea, C. 'Innovation and development: Criteria for organizational performance', Managerial Challenges of the Contemporary Society. 2010;(1):202-205.

24. Tan, L. P., \& Wong, K. Y. Linkage between knowledge management and manufacturing performance: a structural equation modelling approach. Journal of Knowledge Management. 2015;19(4):814-835. https://doi.org/10.1108/JKM-11-2014-0487.

25. Wood, F. \& Sangster, A. 2002. Business accounting 1. 11th Ed. Pearson Education.

26. Wright, P. \& Geroy, D. G. 2001. Changing the mindset: the training myth and the need for world-class performance. International Journal of Human Resource Management. 2001;12(4):586-600.

27. Zikmund, W.G. Babin, B.J., Carr, J.C., \& Griffin, M. (2009). Business research methods. (8th ed.). Mason: South Western College.

How to cite this article: Kumar R. P, Murugaiah $\mathrm{V}$. The impact of job resources on employee performance and organizational performance in southwestern railway. J Manag Res Anal. 2018;5(4):406-411. 